\title{
Research on Correlation between Foreign Language Oral Anxiety, Oral Performance and Gender
}

\author{
Yongyan Song \\ School of Foreign Languages, Jilin Agricultural University, Changchun 130118, China \\ 1012932249@qq.com
}

Keywords: Oral anxiety; Oral performance; Gender; Correlation; Oral teaching

\begin{abstract}
In this study, the subjects are 102 level C undergraduates in grade 2014 from Jilin Agricultural University. Horwitz' Foreign Language Classroom Anxiety Scale (FLCAS) is adopted to investigate the oral anxiety degree of the subjects. The data and the subjects' oral performance are analyzed by using SPSS software package. The independent sample T-test results show that there is no significant difference between oral performance and oral anxiety; there is no significant difference between gender and oral anxiety; but there exists very significant difference between gender and oral performance. According to the research results, in order to improve the quality of oral teaching, the implications are putting forward from the view of teaching reform and updating teaching ideas.
\end{abstract}

\section{Introduction}

The researches done by sociolinguistics are increasingly concerned about the role of gender in second language acquisition because the language and gender are very important parts in the field of sociolinguistics. Language reflects gender differences and gender differences also affect the use of language [1]. Some researches have been done on the relationship between language and gender in the field of sociolinguistics. Most of them have explored the correlation between foreign language achievement and gender, and the correlation between learning ability and gender. The research results showed that the overall second language acquisition capability of female was higher than that of male [2]. In their research Liu Shuhui \& Xia Huiyan [3] found that there were no gender differences in language aptitude in the learning stage of university. Yuan Fengshi \& Zhang Fuyong et al. [4] found in their research on the relationship between gender differences in classroom performance and CET4 scores that there was a significant difference between boy students and girl students in CET4 scores, and the scores of girl students were higher than that of boy students. Kiss \& Nikolov[5] found in their research on the validity of the sets of testing questions on foreign language aptitude for 12-year children in Hungary that the achievements and foreign language aptitude of girl students were higher than that of boy students. Moreover, some scholars and experts both at home and abroad have done a lot of researches on the causes resulting in oral anxiety and the countermeasures to reduce the anxiety. For example, $\mathrm{Wu}$ Wensheng, $\mathrm{Lu}$ Jiamei \& Guo Wei [6] have done the research, "A Cluster Analysis of Various State of Spoken Foreign Language Anxiety for Undergraduate Students"; Zhuang Fan [7] has done the research, "Investigation of Non - English Majors' Oral Anxiety Source"; Zhan Xian Jun [8] has done the research, "Research on the Effect of Scaffolding Instruction to Reduce Oral Anxiety"etc. There are some researches on the factors affecting oral standard and performance and ways to improve them. For example, Shi Minjie \& Wang Jun [9] have done the research, "A Study of Gender Differences of Language Learning Strategies and Its Relationships with Japanese Oral Test Scores". Li Ping \& Liu Liu [10] have done the research, "Multi-factoral Regression Analysis of English Majored Students' Oral Achievement" etc. However, the researches on the correlation between oral anxiety, oral performance and gender are rare. Therefore, this research is on the correlation between oral anxiety, oral performance and gender. The purpose is to offer implications for improving oral teaching by exploring the correlation between oral anxiety, oral performance and gender. 


\section{Research Design}

Research Subjects. The subjects are 102 level C undergraduates in grade 2014 from Jilin Agricultural University, including 55 boy students, 47 girl students, 51 country students, 51 city students, 52 art students and 50 engineering students.

Research Problems. There are three problems to be solved in this research: (1) What is the correlation between oral anxiety and oral performance? (2) What is the correlation between gender and oral anxiety? (3) What is the correlation between gender and oral performance?

Research Tools. There are three tools for researching: (1) Questionnaire, which includes two parts, one is about personal information, including discipline, gender, source and learning time etc., the other is about Horwitz' foreign language classroom anxiety scale (FLCAS). The 33 questions in FLCAS are divided into several dimensions, and the oral anxiety questions include number 1, 3, 9, 13, 14, 18, 24, 27, 31. (2) Electronic version of oral test papers, which includes two parts: reading aloud and answering questions and the total score is 20 points. (3) Oral grading criteria.

Research Methods. This research adopts questionnaire and quantitative analysis. 111 questionnaires are delivered, among them 102 were collected, the effective rate is $91.89 \%$. The data and oral performances were put into computers for descriptive analysis, correlation analysis and independent sample T-test.

\section{Result Analysis and Discussion}

Descriptive Analysis of Each Anxiety Dimension. Descriptive analysis of anxiety degrees of each dimension has been done by using SPSS software package. The result is shown in table 1, see table 1 .

Table 1 Descriptive analysis of each anxiety dimension

\begin{tabular}{cccccc}
\hline Item & $\mathrm{N}$ & Min & Max & M & SD \\
\hline oral anxiety & 102 & 9.00 & 38.00 & 25.5294 & 6.23581 \\
test anxiety & 102 & 5.00 & 23.00 & 13.8922 & 3.49230 \\
communication apprehension & 102 & 5.00 & 22.00 & 14.4608 & 3.33203 \\
a fear of negative evaluation & 102 & 5.00 & 24.00 & 13.7647 & 3.40697 \\
\hline
\end{tabular}

As is shown in table 1, the mean of oral anxiety is 25.5294, which is much higher than that of other dimensions (test anxiety, communication apprehension and a fear of negative evaluation) . This shows that the oral anxiety degree of the subjects is very high. The reason may be that the English standard of $\mathrm{C}$ level students is very low. Even if the students with a little bit higher English standard are afraid of speaking English, fearing being laughed at by the teacher and classmates. Besides, some C level students are sports special enrollment students and minority students, their English level is much lower, and they almost can't speak English. Therefore, the oral anxiety degree of $\mathrm{C}$ level students is high compared with other dimensions.

Correlation Analysis between Oral Anxiety and Oral Performance. Correlation between oral anxiety and oral performance is analyzed by using SPSS software package. The result is shown in table 2 , see table 2 .

Table 2 Correlation analysis between oral anxiety and oral performance

\begin{tabular}{ccccc}
\hline Item & \multicolumn{3}{c}{ oral performance } \\
\hline & $\mathrm{M}$ & $\mathrm{S} \mathrm{D}$ & $\mathrm{r}$ & $\mathrm{p}$ \\
oral anxiety & 25.5294 & 6.23581 & -.080 & .427 \\
\hline
\end{tabular}

Note: $* \mathrm{p}<0.05, * * \mathrm{p}<0.01, * * * \mathrm{p}<0.001$.

As is shown in table 2, there is no significant difference between oral anxiety and oral performance $(r=-0.080 ; p=0.427>0.05)$. The reason may be that although the English standard of $\mathrm{C}$ level students is not high, they have the high ability to communicate with others, and also have 
strong oral communication skills. So their oral performances are higher even if they have high oral anxiety degree.

Independent Sample T-test of Oral Anxiety and Gender. Independent sample T-test is done to explore the correlation between oral anxiety and gender by using SPSS software package. The result is shown in table 3 , see table 3 .

Table 3 Independent sample T-test of oral anxiety and gender

\begin{tabular}{|c|c|c|c|c|c|c|}
\hline Item & & $\mathrm{N}$ & \multicolumn{4}{|c|}{ oral anxiety } \\
\hline \multirow{3}{*}{ gender } & & & $\mathrm{M}$ & SD & $\mathrm{t}$ & $\mathrm{P}$ \\
\hline & male & 55 & 25.164 & 6.379 & \multirow[b]{2}{*}{-0.639} & \multirow{2}{*}{0.524} \\
\hline & female & 47 & 25.957 & 6.104 & & \\
\hline
\end{tabular}

Note: $* \mathrm{p}<0.05, * * \mathrm{p}<0.01, * * * \mathrm{p}<0.001$.

As is shown in table 3, both boy students and girl students have oral anxiety in the process of learning English. Their oral anxiety degrees are higher because the average scores of them are above 25. The reason may be that listening and speaking standards of $\mathrm{C}$ level students are low. They are ashamed of making mistakes in speaking English in class because the students of "after 90s" have strong personality and self-esteem. Therefore, their oral anxiety degree is high, but independent sample T-test result shows that there is no significant difference between oral anxiety and gender $(\mathrm{t}=-0.639 ; \mathrm{p}=0.524>0.05)$.

Independent Sample T-test of Oral Performance and Gender. Independent sample T-test is done to explore the correlation between oral performance and gender by using SPSS software package. The result is shown in table 4 , see table 4.

Table 4 Independent sample T-test of oral performance and gender

\begin{tabular}{ccccccc}
\hline Item & & $\mathrm{N}$ & \multicolumn{4}{c}{ oral performance } \\
\hline \multirow{3}{*}{ gender } & Male & 55 & $\mathrm{M}$ & $\mathrm{SD}$ & $\mathrm{t}$ & $\mathrm{p}$ \\
& female & 47 & 9.213 & 2.734 & $-4.162 * * *$ & 0.000 \\
\hline
\end{tabular}

Note: $* \mathrm{p}<0.05, * * \mathrm{p}<0.01, * * * \mathrm{p}<0.001$.

As is shown in table 4, under the total 20 points, the mean of girl students' oral performances is 11.296 and the mean of boy students is 9.213. The mean of girl students' oral performance is 2.083 points higher than that of boy students'. The result of independent sample T-test indicates that there is very significant difference between oral performance and gender, and the performance of girl students is significantly higher than that of boy students. $(t=-4.162, p=0.000)$. The reason is that according to some other researches, the results of which show that girl students are superior to boy students in learning languages by nature; the oral performance of boy students is lower than that of girl students; for the ability to learn language, girls are better than boys; girl students work harder than boy students; girl students have stronger willpower than boy students. Therefore, the oral performance of girl students is significantly higher than that of boy students.

\section{Conclusion and Implication}

This research did an investigation into foreign language learning anxiety, especially oral anxiety of 102 C level students in grade 2014 from Jilin Agricultural University. The data and oral performances were analyzed by using SPSS software package to explore the correlation between oral anxiety and oral performance, oral anxiety and gender, oral performance and gender. The research results are the oral anxiety degree is higher compared with other anxiety dimensions, but there is no significant difference between oral anxiety and oral performance; although the average scores of boy students' oral anxiety and girl students' are different, there is no significant difference 
between oral anxiety and gender; there is very significant difference between oral performance and gender, or the oral performance of girl students is significantly higher than that of boy students. This research result offers implications to oral teaching.

This research offers implications for the reform of the oral teaching methods and modes: (1) The teaching methods should be flexible and diversity, and teachers should use different forms of classroom activities based on different oral teaching content, such as story-telling, debating, group discussion, role play, pair work etc. to achieve the effect of creating active classroom atmosphere and immersive feeling, thus improving students' interest and enthusiasm, and reducing oral anxiety degree. (2) Teachers mustn't neglect the difference between genders in teaching, and teach students based on the gender from the perspectives of language learning psychology, ability, methods, habits and perseverance etc. to achieve the purpose of improving oral teaching quality [11].

\section{Acknowledgements}

This paper is supported by Jilin Provincial social science funds (2014 WY18)

\section{References}

[1] X.Y.Shi: Gender difference in undergraduates' second language acquisition proficiencyTaking Fujian Agriculture and Forestry University as a Case [J]. Journal of Fujian Agriculture and Forestry University (Philosophy and Social Sciences), Vol.16 (2013) No.1, pp.92-96. (In Chinese)

[2] P.Lai and J.M. Xia: Gender difference in second language acquisition-Multidisciplinary visual Angle Review [J]. JOURNAL OF OCEAN UNIVERSITY OF CHINA (Social Sciences Edition), (2009) No.6, pp. 58-61. (In Chinese)

[3] S.H.Liu and H.Y Xia: A Study on Gender Differences in Second Language Acquisition from Language Aptitude [J]. Journal of Tianjin Radio \& TV University, Vol.15 (2011) No.2, pp.77-80. (In Chinese)

[4] F.S.Yuan and F.Y. Zhang et al.: An Empirical Study of Gender Differences of English Classroom Behaviors of English Majors and Its Relationships with CET4 Scores [J]. Journal of Qinghai Normal University (Philosophy and Social Sciences Edition), (2004) No.3, pp. 133-137. (In Chinese)

[5] Kiss, C. \& Nikolov, M.: Developing, Piloting, and Validating an Instrument to Measure Young Learners' Aptitude [J]. Language Learning, Vol.55 (2005) No.1, pp. 99-150.

[6] W.S.Wu, J.M. Lu and W.Guo: A Cluster Analysis of Various State of Spoken Foreign Language Anxiety for Undergraduate Students [J]. Psychological Science, Vol.32 (2009) No.5, pp.1091-1094. (In Chinese)

[7] F. Zhuang: Investigation of Non-English Majors' Oral Anxiety Source [J]. Journal of Liming Vocational University, Vol.67(2010)No.6, pp. 54-56. (In Chinese)

[8] X.J.Zhan: Research on the Effect of Scaffolding Instruction to Reduce Oral Anxiety [J]. English Teachers, (2014) No.7, pp. 15-20. (In Chinese)

[9] M.J.Shi and J. Wang: A Study of Gender Differences of Language Learning Strategies and Its Relationships with Japanese Oral Test Scores [J]. Journal of Zhejiang Wanli University, Vol.25 (2012) No.5, pp. 111-116. (In Chinese)

[10]P.Li and L. Liu: Multi-factoral Regression Analysis of English Majored Students' Oral Achievement [J]. Journal of Yichun College, Vol.33 (2011) No.6, pp. 189-191. (In Chinese)

[11]J.L.Chen and Q.F. Liu: Paying Attention to Gender Differences and Developing English Learning Potential of Boy Students [J]. Popular Science, (2011) No.5, pp. 47-48. (In Chinese) 